\title{
HYBRIDS OF MIND AND BODY: THE FORMS AND FREEDOMS OF THE CYBORG IN POSTHUMANIST SCIENCE FICTION
}

\author{
By \\ Ben Berman Ghan \\ Bachelor of Arts in English, University of Toronto, 2019 \\ A Major Research Paper \\ presented to Ryerson University \\ in partial fulfillment of the requirements \\ for the degree of Master of Arts \\ in Literatures of Modernity
}

Toronto, Ontario, Canada, 2020

CBen Berman Ghan 2020 


\section{AUTHOR'S DECLARATION FOR \\ ELECTRONIC SUBMISSION OF A MAJOR RESEARCH PAPER}

I hereby declare that I am the sole author of this MRP. This is a true copy of the MRP, including any required final revisions.

I authorize Ryerson University to lend this MRP to other institutions or individuals for the purpose of scholarly research. I further authorize Ryerson University to reproduce this MRP by photocopying or by other means, in total or in part, at the request of other institutions or individuals for the purpose of scholarly research.

I understand that my MRP may be made electronically available to the public. 


\section{Introduction}

The Cyborg as a figure in popular culture - the body in a literal state of "human/machine symbiosis" (Katherine Hayles, How We Became Posthuman 112) - has sometimes been conceived as a monstrous figure, as a figure of otherness, a being whose status as a hybrid has placed them into the figure of what Giorgio Agamben might refer to as "the Homo Sacer, a person [who] is simply set outside human jurisdiction without being brought into the realm of divine law" (Agamben, Sovereign Power and Bare Life 82). The Homo Sacer, in other words, is a being who has been stripped of all recognition and humanity, deserving neither the rights of a

human being or any other animal, and has come to be acknowledged only as an object. Agamben further defines the life of Homo Sacer's exclusion as "unsacrificeability and [yet] is included in the community in the form of being able to be killed" (82), meaning that Homo Sacer can be killed, but that their killing would never constitute murder, as their life has no recognizable value.

Reading the Cyborg as a stand in for Agamben's Homo Sacer, and as a representative of the dehumanization that Agamben sought to illustrate, however, within the contexts of cultural posthumanism, and through the lens of queer theory, the Cyborg has the opportunity to grow beyond the doom of the "double exclusion into which [they are] taken and the violence to which [they] find themselves exposed" (Agamben 82). Instead of allowing their status as monsters devalue them, the cyborg can in fact be elevated by it. For thinkers such as Deborah P. Dixon, the promise of monsters "provokes horror and wonder by virtue of its refusal to be confined within any categorical system other than its own" (672). In agreement with Dixon, Hayles would expand out to acknowledge that while any figure of the posthuman - which the cyborg represents - "both evokes terror and excites pleasure" (283), and for those who do not give in to that sense 
of terror, "The posthuman evokes the exhilarating prospect of getting out of some of the old boxes and opens up new ways of thinking about what being human means" (Hayles 285)

While terror of the cyborg might paint them as "Anti-human" (Hayles 289), and the arrival of monsters signifies that "the days of the human may be numbered" (283), the cyborg is not doomed to this Othering. Instead, positive interpretations of the cyborg stemming from such works as Donna Haraway's The Cyborg Manifesto show the ways that cyborgs and their fellow hybrid monsters throughout many literary texts embody the hopes of thinkers like Dixon, Hayles, and Harrow, and and allow"space for the consideration of a host of new possibilities, of new modes of being and doing" (Dixon 672). Haraway defines the Cyborg like thinkers such as Hayles, a literal fusion of machine and human, but also goes further to encompass metaphorical fusions, arguing that Cyborgs are "creature[s] of social reality as well as creatures of fiction. Social reality is lived social relations, our most important political construction, a worldchanging fiction" (Haraway 5-6), meaning that the Cyborg exists simultaneously in the spaces of our fictions, our reality, and those fictions which we have imposed onto reality, or mistake for reality.

It is the fiction of these social realities that would keep the Cyborg in the place of Homo Sacer, living the imposed fiction that the impure, to have a humanity that has been mediated by non-human elements, is to deserve a lesser autonomy. These social fictions represent that aforementioned terror, terror at the body of monsters that do not conform to heteronormative, socio-normative, or even chrono-normative politics. In arguing that "the cyborg is a condensed image of both imagination and material reality" (7), Haraway presents an opportunity for the Cyborg, in embracing the reality of the human and the possibilities and implications of their posthuman states, to become both positive and subversive. 
Here we speak to a queerness that not only to speak to sexualities found in the LGBTQ community differing from both heterosexuality and heteronormativity in culture, but also to a sense of queerness not fully human or defined, or as Judith Butler would argue, a queerness "never fully owned, but always only redeployed, twisted, queered from a prior usage and in the direction of urgent and expanding political purposes" (Butler, Critically Queer 19). This queerness is not a bug in the texts that I analyse, but a necessary feature of the subjectivity of the Cyborg. As I will show, queerness is spread across its own spectrum of literary cyborgs, ranging from that traditional physical fusion of human/machine symbiosis such as in Ken Liu's The Hidden Girl and Other Stories, but also stretching beyond it. I will examine how queerness presents in cyborgs of inhuman/machine subjectivities that have fused with human bodies. Much of this will delve not only into literal human/machine symbiosis, but the kidn of fusion that author Ted Chiang referred to in his story The Truth of fact, the truth of Feeling as the process of becoming a "Cognitive Cyborg [...] Someone whose thought processes are technologically mediated" (Chiang Exhalation 196). The act of becoming a cognitive cyborg is also tantamount to Chiang's novella Story of Your Life, which will be examined within this essay, following a human body, whose state of fusion exists only in the mind. In contrast to Story of Your Life, I will also find in entirely inhuman/machine bodies that begin to have their thought processes mediated through a human subjectivity, as is the case in of Alan Moore's creative run on the DC Comic's The Saga of the Swamp Thing. Finally, I will search for queerness in bodies that, like Haraway's interpretation, embody states of fusion, possessing bodies that are both human/inhuman, and minds that are human/inhuman, spinning out into ever more complicated states of hybrid being that I will refer to as a Mind and Body Cyborg. 
This Mind and Body cyborg as a queer figure raises its head in Amal El-Mohtar and Max Gladstone's 2019 epistolary novel This is How You Lose The Time War, as two Cyborg bodies showed their previous subjectivities in order to find a queer understanding of one another. But the Mind and Body Cyborg establishes itself in parts through all of the texts I am to discuss. Whether it is in the quest for identity, for purpose, or the many forms of autonomy originally denied the monster, through their altered subjectivities, the post-human Cyborg as a subversive figure is one that can flourish and reach out to one another in new forms of what Haraway referred to as "cyborg writing" (54) that the human world with its various constraints and conceptions of purity could never achieve. For the Cyborg, beyond merely building a body or subjectivity that strays from what the type of body and mind that has been deemed natural, it is the act of writing itself that allows Cyborgs to throw off the shackles of the Homo Sacer. Through the discovery of writing cyborgs not only have the chance to redeem themselves and reexamine their socially constructed identities, but to reach out to other cyborgs like themselves. By becoming authors of cyborg texts, by writing stories onto themselves and each other, Cyborgs have the potential to forge connections and relationships outside the ordinary boundaries of what is "human."

This essay has been broken down into six necessary sections. First, an examination of what posthumanism means in the context of this paper, which elements of posthumanist thinkings are relevant, and what they are referring too. Then, I will spend some time with my chosen texts, helping to flesh out and illustrate the way characters therein become posthuman. Finally, my argument will come to queerness itself, and how the process of becoming cyborg allows an opportunity for queerness to flourish. 


\section{Part 1: What the Monster Must Fight [on Posthumanism and Liberal Humanism]}

The struggle to overcome the dualisms of natural/unnatural and humanist concepts of "purity" is a central conflict of both the texts I am examining, and a critical project in queering the figure of the Cyborg, the hybrid body focused on breaking down the dualisms and binaries of normative human culture. But to understand this resistance, we must also understand the structure of what the queer cyborg must rebel against, much of which is subsumed by the philosophical and political ideologies of Liberal Humanism.

Though full of contradictions and not the fixed idea of any one thinker, the main project of Liberal Humanism could be understood to entirely center the universe around a notion of the human, dismissing any suggestion that history, ethics, identity, or even reality could extend beyond a "pure" human subjectivity. In her article Posthuman Humanities, Rosi Braidotti argued that for the liberal humanist "Subjectivity is equated with consciousness, universal rationality, and self-regulating ethical behaviour, all of them equating masculinity and European civilization, whereas Otherness is defined as its negative and specular counterpart: irrationality, immorality, femininity and non-westernness" (2).

Subjectivity, throughout this essay, refers to how a creature sees its world, and how that creature sees and defines itself as a part of that world. A human's subjectivity, for example, might involve an understanding of linear time and mortality, and an understanding of who they are in relation to others. A dog's subjectivity, by contrast, might be similar to the human's, but not identical, with its subjective understanding of time, and certainly of social structures differing. Further still, how a machine, or extra-terrestrial might perceive of themselves and their universe, is further still from what the human subjectivity perceives. In short, subjectivity will be 
used as a shorthand for how characters are capable of thinking about their external and internal worlds.

Returning to the concept of the Homo Sacer, Agamben argues that what we call a liberal humanist society operates as a kind of extension for what the ancient Romans considered the city. for Agamben, the concept of the city an is not a literal place with structural limits, but the " foundation of social and political life, insofar as its founding establish[es] the critical difference between physiological life (bare life) and community (polis)” (Lord Sowah 2). The city, in essence, is the human world, the civilization that has chosen to define what falls within its borders and what does not. The Liberal humanist city separates the human and places it above all else, but also qualifies what being human means, and only those who meet its standard are granted Poli/community life, with bodies and identities that do not conform being cast out. Within the city, there is also the complication of gender, with acceptance in the city of liberal humanist culture adherent to relying on "the binary logic of identity and otherness" (Braidotti 2) of heteronormative gender roles. To deviate from the binary of man and woman as set forth in the liberal humanist mindset, is to stray from a purely human identity.Posthumanist theorists such as Braidotti and Haraway would argue that an us/them One/Other is the driving force behind liberal humanist thought. Haraway noted specifically that it seems there is an almost “manic compulsion to name the Enemy" (Haraway 9) in order for liberal humanists to keep their definitions firm. Therefore the terror and fear of the monster and the posthuman - of which the cyborg is both - spoken of by Hayles and Dixon, is actually a terror of beings and bodies that threaten the idea of a "Pure" human, that threaten the liberal humanist "desire for mastery [over the world and each other], an objectivist account of scientist, and the imperialist project of 
subduing nature" (Hayles 288), that is also wrapped up in the idea of empire, and subjugation, and colonialism.

Even views of things our cultures classifies as natural, both in the human and non-human world, are not truths, but viewpoints being imposed onto nature, often because the liberal humanist vocabulary is one that embraces the simplicity of One/Other or natural/unnatural, while, as Fritjof Capra states: "The natural world, on the other hand, is one of infinite varieties and complexities [...] where things do not happen in sequences, but all together" (Capra The Tao of Physics 28). If we were to account for most actual living things, plant life and microbes that we can never see, then the myth of heterosexuality as natural, for example, is supplanted by the truth that not only is homosexuality abundant in nature, but most life on earth reproduces asexually. In his article "Queer Ecology," theorist Timothy Morton argues that "Nature looks natural because it keeps going, and going, and going, like the undead, and because we keep on looking away, framing it, sizing it up" (279), refusing to see when it does not fit within the rules we have set down for it. In essence, the social fiction of a liberal humanist culture extends past the policing of bodies, but the policing of the elements of nature, and what is natural.

Within its quest to control what is natural, and to keep control over nature, Liberal humanist thought also branches into what theorist Elizabeth Freeman calls chrononormativity. Chrononormativity, a subset of chronobiopolitics, is not necessarily an argument that linear time is a construct, but that how we choose to value, organize, and segment time is. Western chrononormativity conditions our collective subjectivity to accept "institutionally and culturally enforced" (4) timelines of sequences and cycles that draw a roadmap to human life and human worth that favours capitalism, heteronormativity, and patriarchy above all else. Freeman argues that chrononormativity is "a mode of implantation" (3) through which our subjective view of 
time is arranged to seem objective and immutable. "Schedules, calendars, time zones" (3) are examples of implantations. The enforcing of these arbitrary rhythms is more insidious than just the twelve-month calendar. A person's belonging and acceptance in society can come to depend on how productive they are within a capitalist and heteronormative timeline. The timing for "marriage, accumulation of health and wealth for the future, reproduction, childbearing, and death" (4) are all judged and politicized. In this way, chrononormativity also constrains queerness and polices gender by making the heteronormative conceptions of how gender should develop and present into concrete certainties. The body and identity of the woman become trapped in these cycles and the logic of chrononormativity insists that women should be defined by a linear progression from a child to adult, to wife, to mother, to grandmother, to dead. These identities - Wife, mother, grandmother - are considered as both sequential and inevitable and are deeply harmful to any experience of gender identity that does not strictly adhere to this timeline. This reading of gender is one that adheres strictly to the idea of a natural body, of two clearly defined genders, of a single correct timeline to follow to be accepted as human. The Cyborg's task, then, is to break free from these restrictions, to create a body and a mind that are not tied to these markers of humanity.

In The Cyborg Manifesto, Haraway makes a case that the cyborg might be uniquely positioned to resist such liberal humanist normativities such as hetero and chrononormativity, and the ideal "pure" human body and mind, not in spite of being excluded from the "city" - to borrow Agamben's shorthand term for settler-colonial culture and Western civilization - but because they have no place in it. "The cyborg," Haraway argues, would not recognize the Garden of Eden; it is not made of mud and cannot dream of returning to dust. Perhaps that is why I want to see if cyborgs can subvert the apocalypse [of the need for a liberal humanist One/Other 
dichotomy]" (54). The Cyborg is outside the idea of a "pure" human body, outside of a "natural" nature, and outside of the normative timelines that a heteronormative society feels the need to enforce. I would argue that the more a cyborg embraces their monstrous possibility, the more fusions and incorporations and complications they might take into themselves, the more equipped they might be to resist the heteronormativity of Liberal Humanist culture.

\section{Part 2: Building the Literary Hybrid (Writing, Fear, and Apocalypse)}

This is How You Lose the Time War opens with each of the two protagonists already in possession of two separate types of Cyborg bodies. Red - the agent of a post-singularity "techymechy dystopia" (El Mohtar \& Gladstone 36) - represents the traditional figure of the Cyborg as a human/machine symbiosis, whose "gyroscopes whir in her gut, lenses click beneath the camouflage jelly of those pure black eyes" (14). She operates in a world where these enhancements and implantations are not invasive but natural. Blue - Red's initial opponent, and eventual romantic partner - descends from an opposing "viny-hivey elfworld" (36) future. Blue exists as a body in symbiosis not with the traditional artifice of technology but with a sentient nature represented as "Garden, life to life to life, always deepening, thickening, growing new roots and efficiencies" (74). "Garden" stands as a potential alternative future to the AI intelligence of Red's “Agency [where] we grow in pods, our basic knowledge flashed in cohort by cohort nutrient balance maintained by the gel bath, and most of us stay, our minds flitting disembodied from star to star" that created Red (43).

To continue to call Blue a literal Cyborg like Red, is to return to the posthumanist arguments of queer ecology, and the argument that we cannot easily define what is natural and unnatural. For Blue's cyborg body, we can acknowledge how "Plant sentience and intelligence are $[\ldots]$ explicitly associated with the mediation of machines." (Teresa Castro The Mediated 
Plant 11). Blue remains a figure of human/machine symbiosis, even if that machine has taken a different form (that of a human/plant-machine). Like Red, Blue sees her own body as natural, and Red's as the unnatural. She emphasizes that while the cyborgs of Red's world are created artificially and decanted, the children of Garden are "grown [...] seeds planted, roots combing through time (El Mohtar \& Gladstone 126).

Though each character's idea of what is natural has been changed from what we might consider the liberal humanist standard, they are still determined to hold onto their new dualisms, the imposed war between their two timelines. For Red, the only future that deserves Poli/true recognition, is "the future in which her Agency rules, in which Red herself is possible" (1), just as Blue equally denies the validity of Red's future, and only claims poli life for the future that holds her Garden. Though each believes that only their specific future is natural and deserves to exist. They initially think of themselves as forces and objects that others have set in motions, and their conflict something that was not chosen, but as inevitable and unavoidable as gravity. In an early letter, Blue muses as such: "your unstoppable force to our immovable object; less a game of goes than of tic-tac-toe, outcomes determined from the first move, endlessly iterated until the split where we fork off into unstable chaotic possibility - the future we seek to secure at each other's expense" (El Mohtar \& Gladstone 7). Each belongs not to a certain future, but a possibly one. Neither destiny is naturally occurring, but a destiny they attempt to impose onto the world, all the while denying that an alternate view of nature and being human might be just as valid as the one from which they originated. Though they are physical cyborgs, Red and Blue begin in a state that Hayles argued as a perversion of what it means to be posthuman: "What is lethal is not the posthuman as such but the grafting of the posthuman onto a liberal humanist view of the self" (Hayles, 286-287). Though they are cyborgs, both Red and Blue are tinged not with the 
excitement or pleasure of the prospect of the posthuman, but the terror imposed by liberal humanist frameworks, something they must overcome in order to embrace their monstrous potential.

The struggle of the liberal human vs posthuman state, is expanded upon through the stories of Ken Liu's The Hidden Girl and Other Stories (Saga Press 2020) - where different characters experience either the excitement and possibility, or existential horror at being faced with various new forms of "articulation of humans with intelligent machines" (Hayles 287). In Liu's story Staying Behind, we see a fierce resistance to such articulations - in this case to a form of the posthuman that has become digital, with minds entirely uploaded into an artificial reality, only interacting with the physical world through intelligent machines. The Narrator of Staying Behind represents the pockets of liberal humanist society, a stronger articulation of the fear Red and Blue feel towards each other's differing futures and bodies. The Narrator's community has rejected the call of the singularity and the remaining society "gentle[y] slide[s] back down the technology curve" (Liu 164). As the planet is slowly depopulated of physical bodies, there are no longer enough people left to keep the lights on for embodied civilization. Often, the questions asked by the protagonist of that story pinpoint the concerns of the liberal humanist: "[were those who uploaded] now an artificial intelligence? Or were [they] still somehow human, with silicon and graphene performing the functions of neurons? Was it merely a hardware upgrade for consciousness? Or [had they] become a mere algorithm, a clockwork imitation of free will” (Liu 154)? The question of free will, alongside the importance of continuing one's culture by having children and other values that The Narrator has decided are unquestionable.

Like those granted political life in Agamben's symbolic City, here it has been declared that there "there was a right way to live, and a right way to die" (158), and to break these self- 
imposed rules is to lose recognition as an autonomous human. The Narrator and his community remain adamant that human beings should work to retain their apparent dominance over nature. They believe that by uploading, "humanity was abandoning the world and destroying itself" (158). Without his assurance that those who have uploaded retain that mythical power of free will and human judgment, he denounces their humanity entirely, so that they are only ever referred to as "the dead" (160). To The Narrator, there are the living embodied humans, and the machines which masquerade as the dead, a sinister enemy that is and must remain entirely other, the Anti-Human that is set on destruction. The problem as the liberal humanist sees it is that every human being — the singular containers of judgment/free will—are each an "autonomous self with unambiguous boundaries" (Hayles 290). So anything that muddies the seeming "purity" of these bodies dilutes the very thing that makes them human. When human minds are uploaded, it is not a digital clone or copy of the person but the only remaining version of that consciousness, as the physical body is destroyed during the process. How the digital humans of Liu's narrative, and their cloud-born offspring, rebut the narrator's doubts about whether they exist as sentient or human, lies mainly in how they claim themselves, arguing that it is the mind, not the body, that defines their humanity, and that their changing state of being does not lessen the validity of their lives. Liu's digital humans, and many other forms of cyborgs or monsters, might claim the arguments of Timothy Morton's "Queer Ecology": "How can we ever distinguish properly between humans and nonhumans? Doesn't the fact that identity is in the eye of the beholder put serious constraints on such distinctions?" (278). The project, for many of these posthumans, becomes not to claim poltical/human life for themselves, but to accept the claims made by others, something the narrator of Staying Behind fails to do. 
The Narrator reaffirms his constant fear — not that he or his wife Carol might ever be convinced to upload but that his daughter Lucy could. Despite prizing the liberal humanist concepts of agency and free will and praising the courage of those who "choose to stay behind" (157), The Narrator never considers his daughter's supposed agency. Those of the next generation that choose to abandon the physical plane are not choosing at all, as The Narrator's choice, and way of life, is the only authentic mode of living. Those of the next generation who choose to transcend to a digital existence,

The narrator does not consider the desires of his or his children's generations to transcend into a digital existence to be a valid or legitimate choice. Instead, he sees their decision only as an unforgivable act of suicide, an invalid choice, that invalidates all future choices, a mistake that would doom his child and those like her to becoming a machine with "no hope, only a timeless, changeless, simulated existence as fragments of a machine" (Liu 170). The Narrator fears both that his daughter will submit to the dead and be destroyed but also that without her to carry on the way of life that he has deemed natural, the human world will be destroyed. He reaffirms the Us/Them binary by painting all the cloud-based consciousness as child snatchers: "year after year, relentlessly, the dead try to steal our children" (157). When The Narrator has no facts to attest to his belief that digital humanity is not comprised of genuinely living thinking beings but only copies of the dead, all of his fears and convictions are placed onto the backs of the children. Even when those he claims are mere machines display clear signs of agency, he refuses to acknowledge them as more than Homo Sacer. The Narrator constantly moves the goalpost of humanity, a characteristic which Agamben argues is "one of the essential characteristics of modern biopolitics [...] its constant need to redefine the threshold in life that distinguishes and separates what is inside from what is outside" (131). The liberal humanist has 
already decided that the posthumans are outside the threshold of political life and will move the necessary requirements to keep them there.

The ideas of the posthuman are treated like a virus, or an infection: ideas that can be caught and spread, and must be stamped out, and it seems notable that the danger of this infection rises mainly from written words, from emails and letters that "seek an opening" (158) into the minds of the Narrator and his family.

Though the Narrator of Staying Behind rooted his terror in the misguided belief that the posthuman is the anti-human, his fear that writing could act as a gateway, or an infecting agent of posthumanism, is lent credence all throughout texts such as in This is How You Lose The Time War. The Narrator of Staying Behind constantly goes through his daughters' possessions, her computers, doing his best to monitor all incoming and outgoing writing, for fear that representatives of digital humanity might be reaching out to his family through text. The threat of incoming writing is treated as the threat of plague rats, an infection that destroys the lives that might accept it.

When Red and Blue in Time War speak of being infected or infiltrated by one another both mentally and physically, they often speak of the act of reading as the most potent infiltration point for the writer, with each letter another way for one to dilute the "purity" of the other's subjectivity: "It gives me great pleasure to think of you reading these words [...] unable to keep the letters on a page; instead you must absorb them, admit them into your memory. In order to recall them you must seek my presence in your thoughts $[\ldots]$ you must admit yourself already infiltrated" (El Mohtar \& Gladstone 8). When The Cyborg Manifesto speaks to the Cyborg as a creature of both reality and fiction, Haraway argues that "writing has been crucial to the Western myth of the distinction between oral and written cultures, primitive and civilized mentalities, and 
more recently to the erosion of [those] distinctions" (55). Western colonial culture often helps to distinguish between who deserves Poli life and Bare life not only by who is capable of reading and writing, but also by who adheres to the writing that normative culture has deemed canon, or essential. Adherence to religious texts for example, has always helped define who is human and who is not, Western colonists deeming those who do not swear by the tenants of Christianity to be less human. This is acknowledged in stories like Staying Behind, where the narrator justifies his belief in liberal humanist principles by clinging to the bible, which his mother had used before him. Though his terminology has removed the overt Christian language, its sentiment and dominance remain, and throughout the story, he reiterates the importance of remaining committed to his view of humanity, continually trying to "rekindle the faith" (159) that his chosen way of life is the only correct one. But if writing has helped to enforce such cultural myths as One/Other binaries and heteronormative dualisms, then Cyborgs have the opportunity to rewrite and overwrite such myths with writing of their own.

Though Red and Blue's letters initially seek to infiltrate each other as a form of attack, over time, the act of writing helps to break down the boundaries of the One/Other binary each have held onto. Red, once deep into their written correspondence, acknowledges that their reading of each other has "built a you within me, or you have" (94). The novel treats the act of reading and writing as a way for Red and Blue to trigger personal apocalypses of their subjective notions of purity and otherness within one another, with writing not creating new moments, but new worlds. "Letters are structures, not events. Yours give me a place to live inside" (94) argues Red, illustrating how Blue's words alone have restructured her sense of self, and her sense of belonging. 
In Time War and other stories, we are given an example of how the idea of Cyborg Writing, as detailed in Haraway's Cyborg Manifesto, might help to free the Cyborg from the constraints of dualism and Otherness that might hold them back from each other. Though Haraway originally posited how "'women of color' might be understood as a cyborg identity, a potent subjectivity synthesized from fusions of 'outsider' identities" (54) most powerfully placed to be enabled through cyborg writing. Applying cyborg theory to narratives like This is How You Lose the Time War show how other "taboo fusions made inevitable by the social relations of science and technology" (52) that stray from the notions of purity that are "persistent in western traditions" (59) - such as those inherent in heteronormativity - might also be primed for the act of writing as a transformative process. Haraway argues that one of the primary powers of cyborg writing is "about the power to survive, not on the basis of original innocence, but on the basis of seizing the tools to mark the world that marked them as other" (55). In the case of Time War, Red and Blue's prospective "sides" have already the social fiction that reinforces their world order, that of two binary futures, separate worlds that must kill one another to survive, and never make contact with their respective enemies. Through the rhetoric of war and otherness, Agency and Garden are each enforcing a myth of purity.

But the letters sent and shared between Red and Blue continually infect them throughout the narrative. In both purpose and style, they evolve throughout the novel from only short taunts and cruel allusions of what each believes the other's world to be like, to a "confession of real, curious ignorance" (El-Mohtar \& Gladstone 36) about the other's opposing world. Their ignorance of any real knowledge of one another has been fostered by both Agency and Garden's is broken down by the power of their writing. For figures on the process of embracing their 
Monstrous potential, the power of cyborg writing is an apocalyptic experience, something that the characters experience both spiritually and literally.

Time Wars' preoccupation with ways to instigate such personal apocalypses mirrors the very literal apocalypses on a planetary scale that both Red and Blue seek to trigger through history, travelling "upthread into the stable past or downthread into the fraying future" (10) to infect and destroy timelines by changing events in an attempt to "preserve what matters [for their own sides] and let what doesn't fall to dust: mulch for the more perfect future's seed" (El Mohtar \& Gladstone 60). The planetary apocalypses throughout the story intend not to end the world, but radically alter it. Apocalypse, as applied to subjectivity both in these texts and in the real world, is not the "end to the physical world, per se, but the world as structured for the characters" (Glazier and Beck 5). This posthumanist interpretation of the term is best applied to how Time War treats change in both character and world. Creating not the physical but the cognitive Cyborg always requires these apocalyptic rearranging's of subjectivity in order to wipe away the binaries and dualisms of traditional human culture - binaries such as the strict gender norms of man/woman in a single binary (hetero) normative sexuality, or the dualisms of self/other, human/inhuman, or us/them that would keep the figure of the Queer Cyborg constrained. As Time War applies apocalypse on a global scale by rewriting events, it applies apocalypse on the subjective scale through Red and Blue's literal writing of themselves and each other.

The birth of the Cyborg most often triggers such a post-apocalyptic rebirth in literature by coming into contact with transformative and apocalyptic writing. When looking outside of Time War, the impact of Cyborg Writing upon literary monsters and humans alike is often profound, and all consuming for those writing and being written on. In Saga of the Swamp Thing, the protagonist (the titular Swamp Thing) initially believes himself to be only a literal fusion of plant 
and a human body, akin to the physical human/plant-machine symbiosis of Time War's Blue. Though his subjective understanding of self has incorporated an inhuman body, he still maintains a self-image of a purely human existence underneath, separate and apart from the inhuman. But this notion of human purity is destroyed through contact with writing, when Swamp Thing stumbles upon writing about himself and his own nature. This writing - revealing the origin and truth of Swamp Thing's body and creation—reveal him not to be a human within a monstrous figure but "a mas of plant fiber that had somehow been infected with the consciousness of Alec Holland" (Moore et al, Saga of the Swamp Thing volume one 66).

Returning to the idea of subjectivity being an infection, Swamp Thing becomes an entirely alien body of inhuman origin, whose subjective understanding of the world and the self has become more like the human. Swamp Thing's subjective self after this apocalyptic revelation is no longer that of Time War's Blue, but of a new cognitive symbiosis of human consciousness/plant-machine body. As with Time War, the figure of Moore's comic had already begun as a kind of physical hybrid, but only through writing do they become a new kind of Cyborg through a fusion of human/artifice within the mind alone, free to cast of the constrains of their previous understanding of the self.

But the mode of becoming Cyborg can take on many different forms. Whereas for Swamp Thing the apocalypse was an entirely and totally personal event, in Ted Chaing's novella Story of Your Life, the protagonist Louise Banks correctly identifies how her personal apocalypse and a global/societal apocalypse coincide "when ships appeared in orbit and artifacts appeared in meadows" (Chiang 2). In Chiang's global apocalypse, the mere arrival of the alien is enough, as the presence of otherworldly beings forces the Earth to re-examine the ideas of "human exceptionalism" (7) that is assumed by humanism. However, while the mere arrival of the 
Heptapods is the epoch for the global apocalypse in Chiang, for Louise, their arrival is only "how it began" (Chiang 2). While Story of Your Life only briefly concerns itself with the global apocalypse that the Heptapods herald, Chiang's narrative keeps its focus on Louise's more personal apocalypse: the restructuring of her subjectivity. The radical change to Louise's subjectivity goes beyond the presence of the alien, and actually hinges on the insights forced onto Louise by the Heptapods' languages, and more specifically the Heptapod written language, which gives birth to Louise's own "unique sense of apocalypse" (Glazier and Beck 5).

The Heptapods" written language - what Louise refers to as "Heptapod B" (Chiang 14) — suggests a version of temporality unlike the "sequential mode of awareness" (31) that Louise had previously experienced. Where human language - analogue language - uses separate symbols to act as signified/signifier for one another, Heptapod B suggests a "digital" mode of temporality, where there are no separate words or terms that can represent signified or signifier (Glazier and Beck 12). The Heptapods "experience events all at once" (Chiang 31) without being bound to sequence or linear cause and effect, and they express this "simultaneous mode of consciousness" (Chiang 32) through Heptapod B. Louise's pre-apocalyptic life was "before [she] learned to think in Heptapod B" (Chiang 35). While there are instances where Louise truly experiences "past and future all at once" (36) as Heptapods do, Louise's subjectivity becomes "an amalgam of human and Heptapod" (Chiang 35). Louise's after(-)life language revises her concept of the subject, as it forces her to reconcile different identities through her life. Her new subjectivity revises her many identities through time as single, married, divorced, childless, pregnant, a mother, and a mother grieving for her child, into a single digital sense of self. Louise as a kind of cognitive cyborg of human and non-human was forced to cast aside the idea of a "stable, coherent self" (Hayles 286). The personal apocalypse that Louise experiences through 
this new language is one that shatters her humanist, static identity of "I", into an "I" of many simultaneous "multiple selves" (16). Louise's apocalypse ultimately results not only in a change but a radical expansion in her subjectivity.

\section{Part 3: Distributed Cognition and Hauntology}

A major theme throughout the process of becoming posthuman in all the cases that have been discussed, is a dissolution the idea of the human body as the absolute container throughout time and space. Hayles, in arguing the positive benefits of a closer union between humans and intelligent machines argued that "The Body itself is a congealed metaphor. a physical structure whose constraints and possibilities have been formed by an evolutionary history that intelligent machines do not share" (284). Hayles argued instead that such creatures as the posthuman cyborg would instead implement what he referred to as a distributed cognition, where the elements that make up a being's subjectivity such as thinking and judgment are shared and "done by both human and non-human actors" (290). On a microscopic level, this is true of all cyborgs, such as Time War's Red, who have delegated differing functions of their body and thinking between organic and mechanicals agents, incorporating them all into herself. But to expand the idea of a distributed cognition outwards, might be to return to Ken Liu's The Hidden Girl, where digital (post)humanity has found "more sophisticated [ways of thinking] about virtual technologies," human minds spinning endlessly outwards into a digital cloud (290).

Moore's Swamp Thing, as well, can be defined as distributed cognition. Swamp Thing's subjectivity is not "located solely in consciousness" (Hayles 291) but emergent from the "noise crash[ing] within as well as without" (291) the human form. As the comic goes on, Swamp Thing becomes less and less signified by a body, becoming a consciousness continually growing new physical forms, until Swamp Thing \#56, as the creature's cognition becomes distributed 
across the surface of an entire planet, driving multiple bodies, none of which claim a power to agency or judgment over the others as the Swamp Thing's consciousness "resolves itself... into a pleasing... integrated whole" (Moore et al, Saga of the Swamp Thing volume four 200). Despite the character's seeming monstrousness, this embrace of an expanded distributed cognition does not diminish his identity, but, as in Hayles arguments, their "full expression of human capability can be seen precisely to depend" (290) on their expansion.

At first glance, the issue of a distributed sense of being vs an individualized embodied consciousness seems to be one area where This is How You Lose the Time War seems to fail, and in fact, the narrative seems to push in the opposite direction, with both characters drawing inward, from a state of distributed subjectivity to singular and embodied being. Red's world is one of connection, a species all plugged into one another where "there is no mono-we, there are many uses [...] pieces layed atop pieces" (El-Mohtar \& Gladstone 43). Red's cyborg civilization is supposed to be the one where the entire human race is in a constant state of symbiosis. Similarly, the reality of Blue and her Garden demands one be a part of a greater whole, and though she is "enmeshed in this wholeness - they are not the whole of me." (72). Indeed, the concept of queering the cyborg as a whole seems to reject the idea of distribution, instead embracing individual expression and sexuality.

But, to incorporate this posthuman idea of distribution into narratives like Time War and queer cyborgs, and additionally to home in on how becoming cyborg frees one from liberal humanist constraints, and specifically how becoming cyborg can free monstrous figures to embrace a queer expression of themselves, we have to expand the methods of distribution outwards, away from literal distribution with AI and human bodies, and begin to consider the other ways in which these texts allow cyborgs to distribute their identities, through time as well 
as space. For this we return to Freeman's arguments concerning chrononormativity and hauntology, so we may consider the ways that time travel and the act of writing itself play a role in distributing and freeing these characters.

In Chiang's short story, The Truth of Fact, The Truth of Feeling, the narrative is split between two different ages of technology, and two different moments of a culture becoming a type of cognitive cyborg. The near-future narrative, with what might be the more obvious case, shows the impact of how being able to digitally record and rewatch memories using an implanted AI alters society, with the narrator initially worrying that the use of such machines will destroy human beings' ability to appreciate organic memories. But this modern-day narrative is juxtaposed with that of a society's first exposure to writing, and how the written word altered the way memories and understandings of time were mediated through writing, as much if not more so than they might one day be mediated by machines. Andy Clarke in Natural-Born Cyborgs: Minds, Technologies, and the Future of Human Intelligence, proposed that a Cyborg could be created out of any fusion between the "pure" human and the use of any artifice that the human might use to express themselves or enable their identities. Clarke alludes to the use of writing utensils, digital platforms, and other technologies that can become an extension of the self without the literal "intrusion of silicon and wire into flesh and blood, as anyone who has felt himself thinking via the act of writing already knows" (5). This is the conclusion that Chiang's narrator comes to as well, the acceptance that "we became cognitive cyborgs as soon as we became fluid readers" (Chiang 226).

Distribution to writing is both essential to the other relevant Chiang story discussed in this paper, as well as This is How You Lose the Time War, as not only do the posthuman's of both narratives experience the personal apocalypses that drive them to become posthuman 
through writing, but both allow writing to alter how they are distributed through time. In seeking ways to resist chrononormativity, Freeman first points to how art and literature as matters of emotion and imagination can exist outside the timelines of chrononormative production and all work to alter our subjective experience of time. These are often imperfect alterations, as the production of art often follows capitalist chrononormative sequences. When I talk about time travel as a weapon of queer culture and against chrononormativity, I am speaking conceptually not of a linear time machine that can travel up and down a time stream a la Robert Zemeckis' Back to the Future (1985) where the past, present, and future become wholly separated countries that can be visited, left, and returned to, but of a time travel that is an unmooring. Part of a rebellion against chrononormativity is, to borrow a term from Kurt Vonnegut Jr's 1969 novel Slaughterhouse-Five, to become "unstuck in time" (Vonnegut 24) and to become unmoored from the way chrononormativity would demand bodies structure their sense of identity, something which the posthuman might begin to do through writing - though writing, literature, and art cannot be the end point of this break.

“There's a kind of time travel in letters, isn't there?" (El-Mohtar \& Gladstone 42) muses Red, as she and Blue create a correspondence that stretches the boundaries of time and space. As Red and Blue grow their bond through both metaphorical and literal time travel, they enact what Freeman might consider a "Queer hauntology exercise” (Freeman 13). Hauntology was a term coined in Jacques Derrida's work Specters of Marx, an extrapolation of the idea that Karl Marx's theories argue for "an ethics of responsibility towards the other across time" (9). Hauntology exists in a space where history continues to interact with the present, the figure of the ghost or the dead are not removed from us, but still present in our social and cultural consciousness, even 
though we cannot reach through time to act on this responsibility. The dead call for a "different future" (9) than the one we can deliver to them, for possibilities now lost.

We might see a happening out of sequence in Story of Your Life through "the asymmetry in our relationship" (Chiang 20) Louise has with her daughter. By reconciling her various identities in time into a digital unit, Louise must identify her daughter as both a separate entity and as a part of herself, as she identifies herself as both being a mother and as still being pregnant with her child. Louise struggles to see her daughter as more than an "extension of [my]self" (20) and is only sometimes capable of allowing difference between herself and her daughter to serve as a reminder "that you are clearly, maddeningly not me. It will remind me, again, that you won't be a clone of me [...] you won't be someone I could have created by myself" (Chiang 13). At first glance, it could be argued that Chiang's story is about becoming aware of chronogeopolitics, but not rejecting or resisting it. Louise ultimately choosing to still embrace acting out the timeline set for her, even though she is aware of its artifice. But this seeming embrace of chrononormativity and a doomed heteronormativity will become muddled, as the queer aspects of the cyborg become clearer.

Hauntology takes a "collective past" (Freeman 14) and brings it into both the collective and personal present. When we experience hauntology, we are not trying to "write a lost object into the present" (14) but experiencing the past as something still directly happening and affecting us. Through hauntology, we experience "the present itself as a hybrid" (14) of collective pasts and futures, such as Louise does, and as Red and Blue might, constantly experiencing time out of sequence. Red and Blue create a hauntology for each other by allowing both to engage in Cyborg writing as an active, rather than passive process as they each receive their apocalypse through contact with the writing. Neither Red nor Blue are limited to the role of 
author or audience, but rather both serve as reader and writer for one another, each allowing the other a chance to redefine what it means to be a hybrid for both.

\section{Part 4: Return to Cyborg Writing: Origin Stories and Futures}

In Time War, when Red and Blue's early letters speak of infection and infiltration, it is only in binary terms, each fearing the other is trying to entirely convert them to the "enemy's" side. “Are you trying to recruit me?” (El-Mohtar \& Gladstone 36) Blue asks, when Red first reaches out with questions that seek to understand more about her counterpart. However, Red and Blue's letters to one another move into Cyborg Writing once they begin to seek understanding over conversion. Curiosity and desire drive them to each attempt to communicate on a deeper level than that of two soldiers on opposing sides. When Blue is no longer able to maintain the façade, they begin to question why their correspondence continues, and that questioning reveals the doubts about their own writing as well. "What do you want from this Red? What are you doing here? Tell me something true or tell me nothing at all" (37). This desire from each cyborg to say something true about themselves to one another begins to drive their continued writing, and with this quest for truth Red and Blue move past writing in stifling binaries into the realm of storytelling, each attempting in letters to write their own origin stories to one another. Haraway also defines Cyborg writing as the act of "retelling stories, versions that reverse and displace the hierarchical dualisms of naturalized identities." (Cyborg Manifesto 55). From the beginning, each origin complicates the binary definitions of what each Cyborg believes the other to be.

Red and Blue are each given the chance to write origin stories for themselves, stories that might differ from what their respective societies would have written for them, and ones that rewrite the binary view of otherness that each had projected onto the other. Red's cyborg 
civilization is supposed to be the one where the entire human race is in a constant state of symbiosis with machine minds, that very traditional definition of a distributed cognition along the lines of The Hidden Girl. This is as much the identity that Red's agency projects as well as what Blue perceives. However, the origin story that Red writes for herself destroys that image of constant connectivity with a tale of isolation and solitude, moving from a state of distribution to embodiment. Red knows that Blue's assumptions about her are subsumed within Red's identity as a part of one massive "artificial god the size of mountains, built for making war in the far reaches of the cosmos. Imagine that great wait of metal all around [Red], pressing her down, giving her strength, its hoses melding with her flesh" (El-Mohtar \& Gladstone 64). But Red does not write an origin story of world-breaking machines or a call to war. She demands that Blue "Imagine she shears the hoses off, steps out: frail, sapped, weak, free" (64). Red's Cyborg writing asks Blue to reimagine her idea of Red as a small girl who has purposefully walked away from the whole, and severed her connection, embracing isolation on an empty world. "I refused to let them see me. the only person on that tiny rock, and I made the world go dark" (63). In writing her origin story, Red not only takes control of how she is observed by Blue, but it also allows her to subvert the myth of purity that her culture has placed upon her. Though Red's culture is one of vast sameness, in her writing she can label herself "deviant" (64), as something other than only the cultural norm enforced upon her by both Blue's perceptions and Red's society.

Similarly, the origin story Blue writes for herself is one not subsumed by the myth of purity that is her culture and tells a story that forces Red to consider her as an individual, both a part of and apart from her Garden. Blue, like Red, chooses not "to begin my life with the beginning of my life" but with a coming of age which she feels define herself (120). But where 
Red told a story of seeking solitude in her youth, Blue chooses an origin story focused on vulnerability and involuntary isolation. Even Blue's origin story is one rife with infection. She speaks of having been "compromised by enemy action" (120) that sparked a sickness in her that threatened to infect the Garden, and when she "turned all of myself toward Garden to be fed, to stem this, to stop me from disappearing - Garden cut me off' (121). Blue's origin story is that of going from a being entirely distributed to a being entirely embodied. She signals her individuality by contrasting how Red had made "aloneness for yourself apart from the others as a choice - But for me, I was only my own body [...] it was as if I'd become Garden - so me in my wholeness" (121). In the choice to create and share these origin stories of themselves for each other through writing, Red and Blue act as not only as readers of cyborg writing, but as cyborg authors. Haraway's idea of cyborg authors were of storytellers capable of derailing Liberal humanist narratives: "cyborg authors subvert the central myths of origin of Western culture. We have all been colonized by those origin myths, with their longing for fulfillment in apocalypse." (Haraway 55).

Over and over, the Cyborg writes and rewrites their origin stories, even after their first instance of apocalyptic change, such as can be seen in Saga of the Swamp Thing as well. Swamp Thing receives a second new origin when visiting The Parliament of Trees, encountering other monstrous figures such as himself. Swamp Thing enters believing "My creation... was an accident [...] My consciousness borrowed from a dead man" (Moore et al, Saga of the Swamp Thing Volume four 120). In a way, by living with only this origin story of victimhood, Swamp Thing had continually othered themselves, not truly granting themselves political life. Agamben argued that "One of the essential characteristics of modern biopolitics [...] is its constant need to redefine the threshold in life that distinguishes and separates what is inside from what is outside" 
(Agamben 131). But through Cyborg writing, retelling, and reinventing the stories of who and what they are, Cyborgs can effectively reverse that violence, taking what was once outside and bringing it in.

The Parliament of Trees gift Swamp Thing with a new origin, as a "necessary creation... of the world..." (120). For Swamp Thing, this later gift of rewritten origins is also accompanied by a kind of hauntology of itself, learning that they are not the first of their kind, but one of a cycle, a story of violence that is done against monsters, and the violence involved in the creation of monsters. In the parliament, Swamp Thing is gifted this origin in a very literal act of hauntology, encountering a previous incarnation of themselves that show the responsibility they have to one another across time: "all... our stories... are subtly... different... yet the underlying... pattern... remains constant. A man... dies in flames... a monster rises from the mire... sacrifice... and resurrection" (121). Here, Swamp Thing perhaps embodies Deborah Dixon's idea of the monster better than any other, as a "mixture of realms, the animal and the human, of bodies, of sexes, of life and death" (680). But while Swamp Thing experiences so many transformative origins, it is always a passive experience, something others write onto them, not necessarily a story they have chosen to write for themselves. They are only given the chance to become an author through their romance with Abigale Arcane, an act of writing that allows the queerness of their romance to flourish, but also queers both characters.

\section{Part 5: Queering the (swamp)Thing}

To queer Swamp Thing, a character who presents as masculine and accepts he/him pronouns, while in a romantic/sexual relationship with a cisgendered woman, we have to read both Swamp Thing and masculinity through the lens of queer ecology. For Timothy Morton, queer ecology blurs many of the binaries between human/non-human, as well as the binaries of 
male/female gender. "Queer ecological ethics might regard beings as people even when they aren’t people” (Morton 279), Morton argues, and while Swamp Thing's many apocalyptic rebirths and retold origins do take the character on a journey to becoming definable as both a person/non-person, this journey also muddles the idea of gender for the monstrous character. The liberal humanist idea of gender, subsumed in an encompassing view of nature, would argue that "Masculinity performs no performance [...] Masculine is Natural. Natural is masculine. Rugged, bleak, masculine Nature defines it- self through contrasts: outdoorsy and extra- verted, heterosexual, able-bodied — disability is nowhere to be seen; physical wholeness" (Morton 279) is valued above all else. But the body and identity of Swamp Thing erode such fictions. Swamp Thing's body might only be perceived and gendered as male, only through the viewers' assumptions of maleness. Not only is any masculine identity a performance for the monster, but all organic identities are, for a being whose body is a collection of moss, and trees, and other growing things. Swamp Thing has no true gender, no true sex, and no true body, for his consciousness grows and embodies different forms in different locations created from many different natural materials.

Abby, a long-time companion of Swamp Thing, professes her love for the monster and they both acknowledge the queerness of their passion for each other. While they initially experiment with the far more normative action of kissing, which is not unpleasant for either Abby claiming his kisses taste "like Lime... but not as sharp" (Moore et al Saga of the Swamp Thing Volume 3 206), the simple vastness of their differing bodies might be enough to make such an action queer to Morton, in that "Tree hugging is indeed a form of eroticism" (Morton 280). But both characters acknowledge that they "need more from love... than the taste of lime $[\ldots]$ there should be... some form... of communion" (Moore et al 207-208). Swamp Thing and Abby 
find a way to explore their sexual union in a way that is outside of the heteronormative understanding of sex and of connection in an act of unorthodox cyborg writing. For their union, Swamp Thing grows a unique type vegetation, plucking it from his body and offering it to his partner, which Abby eats with his consent. This is not an entirely symbolic act, but one of deep sharing, and ultimately an act of writing, and authorship for Swamp Thing that the character has achieved no other way.

Throughout the many texts involved in the act of Cyborg Writing, which count as writing is often stretched outwards beyond literal words on a page. Like the queer ecology challenge to our idea of natural nature, such acts also challenge our idea of natural writing. To quote another Ken Liu story The Bookmaking Habits of Select Species "every species has its unique way of passing on its wisdom through the ages, its way of making thoughts visible, tangible, frozen for a moment like a bulwark against the irresistible tide of time. Everyone makes books" (Liu The Paper Menagerie and Other Stories 1). In a posthuman universe, one with many different modes of being outside of normative humanity, there must be as many different ways to write. In This is How You Lose the Time War, Red and Blue's letters morph from literal ink and paper, to reading messages in bark of trees, or the taste of tea, or by consuming sumac seeds. "She eats the first three seeds one by one [and] as each letter unfolds in her mind, she frames it in the palace of her memory" (El-Mohtar \& Gladstone 101).

Swamp Thing is able to rewrite Abby's perspective of who and what he is through this unorthodox act of writing, as it begins to temporarily warp and change her perspective of the world around her. But this is not a hallucination, but a rearranging of her subjectivity, alongside her partners. "You ate... the fruit... Abby... you absorbed... a little... of my consciousness... my perceptions" (Moore et al Saga of the Swamp Thing Volume three 212). Like in Time War, 
we must read the eating of the fruit in Swamp Thing as both a literary and sexual act.

Throughout the panels of pages of 216-219, the art of? Stephen Bissette and John Toltleben takes on an ecstatic and sensual tone, taking the reader with Abby as she explores the subjectivity of Swamp Thing, as the narrator defines the way in which both characters are moving beyond the human/non-human I/Other boundaries, describing it as "a blazing cat's cradle inside me, inside him... where we touch, the fibers merge and interchangeable. I am no longer certain where I end... and he begins... I feel my own hand as he feels it [...] we are blurring together" (214) and though the narration seems to indicate that it is Abby speaking, the colour and texture of the speech bubbles obscure whether some of the narration comes from Swamp Thing himself. The narration and art frame this experience as sexual, forcing readers to "To contemplate ecology's unfathomable intimacies [and] imagine pleasures that are not heteronormative, not genital, not geared to ideologies about where the body stops and starts (Morton 280).

In Swamp Thing we see a creature who allows themselves to grow and expand within the definitions of their monstrous identity. Through their many experiences of rebirth and transformations through writing, the Swamp Thing and Abby eventually create a romance together that is intrinsically queer,, a queerness that is not impaired by their monstrousness, but is in fact enabled by it, and only made possible by the many fusions that have made the Swamp Thing a hybrid.

But where Swamp Thing succeeds in queering itself by the process of being written on by others, and then ultimately writing on another himself, This Is How You Lose the Time War takes the cyborg's journey towards queerness and fusion one necessary step further, fusing the experience of hauntology directly into the act of reciprocal cyborg writing. Red and Blue create very real hauntologies for each other by allowing both to engage in Cyborg writing as an active, 
rather than passive process as they each receive their apocalypse through contact with the writing. Neither Red nor Blue are limited to the role of author or audience, but rather both serve as reader and writer for one another, each allowing the other a chance to redefine what it means to be a hybrid for both.

\section{Part 6: A Cyborg Hauntology, and the queerness of time travel}

While sharing each other's origin stories through writing is an act of empowerment and fusion - empowering Red and Blue to tell their own stories, and making their writing a part of each other in the process - Time War goes further, giving Red and Blue a chance to retell the other's origin once they have told their own. Already armed with each other's origin stories, Red and Blue get to write again, except this time they write not onto the story of themselves, but the story of each other, by each entering and becoming a part of the stories they had told each other. Blue, sent back in time to Red's childhood, witnesses first-hand the origin story Red had written "Blue looks at red - thirteen, alone, vulnerable, so impossible fragile and small - and a letter rises up in her throat" (El Mohtar \& Gladstone 75). But Blue becomes more than an observer of Red's story. She was sent there by Garden, to continue to prop up the war of their two sides by bringing a monster to kill an enemy agent. But when Blue sees the monster head towards its target, Red, Blue intervenes in history and Red's story and "tears out its throat" (76). In doing so, she becomes the "something like a wolf" (63) that Red had encountered in her story, forever writing herself into the origin that Red had written. Similarly, and perhaps more directly, while Blue recounts her childhood sickness as the origin story that sparked her sense of isolation, she remembers that initial infection only as "a kiss and something to eat. It was so kind; I couldn't fathom it as unfriendly. As fairy tale as it gets really. I remember bright light, and then - hunger" (122). But again, through time travel, Red blurs the binaries of past and present and future, 
pressing them together, becoming the being who originally infected Red, inoculating her against the poison that Red's Agency will later attempt to use to kill Blue.

Both of these retellings allow the two Cyborgs to redefine the stories of their origins from events of barely surviving "enemy action" (121) to an event of being protected by a loved one, of being nurtured and understood. In this supreme act of haunting one another through time, Red and Blue weave themselves into each other, and in doing so, they grant the desires that their origins had originally inspires. "I want to be seen" (75) each had professed to the other. When Blue travels into Red's origin, making herself a part of that act of cyborg writing, she describes that "she sees her and breaks like a wave" (75). What each cyborg describes is not seeing one another as enemies, or through the binary of otherness that had been imposed upon them, but seeing one another as they wished to be seen. Having shared this act of cyborg authorship, Red and Blue can no longer continue along the constraining dualism that their cultures insist upon. As embrace each other's writings, each taking the other's story into their own, Red understands that "it's wrong to call you enemy" (79). It is in the death of the idea of the enemy that the figure of the Queer Cyborg can finally be born. Red, having broken the binary holding her back, is allowed to admit, "I love you, Blue. Have I always? Haven't I?" (129). If the Cognitive Cyborg is a Queer Cyborg, as they are in Time War, it's the breaking down of the dualisms and restrictions inherent in a heteronormative subjectivity that necessitates that queerness.

The body and mind under heteronormativity work to "affirm a structure, to authenticate [the] social order" (Edelman 2-3) that man/woman is an absolute binary, that there are two genders, and that there are two sides to a single "pure" sexuality (that of heterosexual couplings).All of which is subsumed under the politics of what queer theory labels "reproductive futurism" (3) - the idea that the goal of all couplings must be to produce children, that by 
"transmit[ing life] to the future in the form of its inner Child" (3), life and romance gain their only meaning. If the goal of cyborg writing is political - and all writing is political - then "Cyborg politics" (Haraway 59) of cyborg writing is queer politics as well, a political statement in finding meaning and connection outside of such norms as reproductive futurism. The Cyborg does not adher to the chrononormative structures of western colonial culture, and instead can build new calenders for themselves, and new timelines where they choose their own sence of significance. These binaries, imposed by culture and not nature, can be cast aside by those who reject the absolute power and authority of such binaries.

As Red and Blue fall in love, Red states, "I want to be a body for you" (El Mohtar \& Gladstone 129), reflecting similarly Swamp Thing's desire to become a body for Abby, something that each of them can connect to. The body, as constructed in cyborg politics, stands as opposed to the body and its purpose under heteronormativity. Though Red and Blue appear to be choosing embodiement over distribution, by sharing and linking themselves to one another, they create that other kind of distributed body shared by two, just as Swamp Thing and Abby become connected to one another through the cyborg authorship of the shared fruit. Queer/Cyborg bodies and Queer/Cyborg politics are bodies of "those not fighting for the children [but fighting on] the side outside the consensus by which all politics confirms the absolute value of reproductive futurism" (Edelman 3). The queer Cyborg is free to "subvert the structures of desire, the force imagined to generate language and gender" (Haraway 57). The binaries of man/woman, mother/father, and parent/child are not necessary destinies for cyborgs, who are free to seek out other forms of coupling, and pursue other desires. Morton argues that under queer ecology, such creatures as monsters force us to question "How do we think about life-forms and their diverse sexualities and pleasures" (Morton 276). The practices of queer 
ecology encourage us to think about the value of the pursuit of pleasures outside of our ideas of reproduction, or, in Red's own words: "Sex improves when decoupled [...] from animalistic procreative desperation" (El Mohtar \& Gladstone 50). Cyborg's bodies, unbound from the "purity" of the human body that is promoted by normativity, and indeed heteronormativity, do not need to "dream of community on the model of the organic [nuclear, or reproductive] family" (Haraway 9).

In some ways, not all the forms of posthuman cyborgs that I have discussed throughout this paper accept the calling of this queerness and its rejection of reproductive futurism. For example, Story of Your Life revolves around Louise choosing to become a mother even with the clarity of her alien subjectivity; the posthumans of The Hidden Girl never entirely dismisses the arguments of reproductive futurism; and, lastly, near the end of Staying Behind, the only rebuttal given to the narrator is one that continues to support the importance of creating new generations: "We have children now [...] we've figured out how to create children of the mind, natives of the digital world. This is the next step in our evolution" (Liu 170). But in these texts, even if they do not totally fufill their queer potential, do at least alter what the possibilities and binaries of parent and child might entail. In The Hidden Girl, for example, the cloud-born are not the results of heteronormative couplings, but instead, human minds of the cloud "decompose [their] consciousness into their constituent algorithms" (Liu 210) until they could isolate the many different agents running programs that make up who they are, the algorithms of their being. "Each of our parents gave us some of these algorithms, recombined and shuffled the routines during the process of our births until we were whole persons, infant consciousnesses new in the universe" (Liu 210). 
In The Hidden Girl, asexual reproduction has supplanted heterosexual, the many agreements of agents running programs randomized until "randomness [can become] not simply as a lack of pattern but as the creative ground from which pattern can emerge" (Hayles 286). This is how Hayles argues subjectivity truly emerges. In embracing the makeup of consciousness as merely agent-running programs, the posthuman has also embraced Haraway's argument that "No objects, spaces or bodies are sacred in themselves; any component can be interfaced with any other if the proper standard, the proper code, can be constructed for processing signals in common language" (Haraway 32). However, for the cloud-born, being disseminated down to lines of code is no more dehumanizing than a biological human's acknowledgement of having DNA. Liu's cloud-born stand as evidence of Haraway's argument that the cyborg model of community and family could shed the heteronormative limitations of their more traditionally "pure" human relatives. Renée - one of Liu's cloud-born characters—is the result of "eight parents" (Liu 210), each of whom contributed "a part of themselves, yet the parts changed and combined into [Renée], different from them all" (210). The human family is no longer limited by the normative groupings that Haraway believed the cyborg could break free from, and instead, "The cyborg is a kind of dissembled and reassembled, postmodern collective and personal self" (Haraway 163). The artifices of binary gender, and binary sets of parents, and even the simple binary of parent/child, has been disrupted by a digital existence where each child can have hundreds of parents, and through each one, the child has the potential for thousands of siblings, "fractional siblings" (211) with which they might share only one parent or dozens until, over time, a cloud-born child might have to track their family tree backward through the generations until they find the influence of an "ancient" human who had once been physically embodied and then uploaded. Nevertheless, the cloud-born children of Liu's new world would not see this as a 
dilution of the human, but merely a different origin for one of the many agent-running programs that make up the entirety of their being.

Similarly, it can be argued that in Story of your Life, Louise's "memories of destiny" (Glazier and Beck 16) radically alter the motives behind parenthood in a way that removes that element of reproductive futurism. Louise argues that knowing the future necessitates a change to one's subjectivity the way hers has changed: "the experience of knowing the future changed a person" (Chiang 29). She is filled with a "sense of urgency" (29) to the future that speaks to the hauntological concept of a responsibility across time, and she chooses to reproduce knowing that her future does not belong to her child, as she knows and accepts her daughters inevitable death. Louise, unmoored from sequential time, sees years that her daughter is alive as still ongoing, even when she is dead. Though her daughter is destined to die, Louise is motivated for events to proceed as her memories of destiny dictate, because of the importance that she believes the events her daughter's life holds.

Both of these supporting texts speak to the argument that queer couplings of course can have children (and heteronormative couples who choose not to reproduce are equally valid), and queer parents are as capable and legitimate as any other parent type. Edelman's argument is not that queer culture cannot produce children, but instead that queer culture is one where the end result of love and couplings does not necessitate children, with love flourishing beyond the normative demand that reproduction be the end goal of coupling. Cyborgs are free to pursue new modes of community and ideas of love through their altered states of subjectivity, their hybrid status, and their place as a fusion of different modes of thinking/being. This cyborg idea of love is not a separate concept from that of queer love under Edelman's argument, but is an expression of queer love. Cyborg love, as Red and Blue love each other, is a love without the motivation of 
creating future generations, or a love constrained by the pressure to do so. They do not aim to find children, or necessarily a place within child rearing culture, but instead aim only to find each other, without the ulterior motives or directives that (hetero)normative culture might demand of them. They do not dream of procreation, but only of one another.

For the two hybrids of This is How You Lose the Time War, the choice to become that cognitive Queer Cyborg through writing is embraced both as a state of mind, and as a physical manifestation. As Red completes her apocalyptic transformation, she "reads Blue into her: tears, breath, skin [...], she builds a model of Blue's mind from the words she left; models her body to the letters' measure" (El-Mohtar \& Gladstone183). Red takes the Cyborg writing of connection and origin and takes it into herself until "new organs bloom from autosynthesized stem cells to shoulder old bits of her away [...] a different mind plays around the edges of her own" (183). Red becomes a new fusion, human/machine and human/plant-machine, forsaking all normative concepts of purity and dualism as she becomes a hybrid that is capable of crossing back and forth from the post-singularity future of her Agency to the Mediated Plant future of Blue's Garden. Still a cyborg of Agency's origins, Garden rejects her. Nevertheless, no longer the pure Cyborg of her own culture, she cannot be accepted back. Her Agency, strictly adhering to the dualism of Us/Them, cannot accept the queer Cyborg as a creature no longer playing within the rules of normative dualism.

The queer body of the Cyborg, that which has been achieved by an apocalyptic shift of subjectivity, cannot exist within binary culture. A queer culture, a cyborg culture, is a hybrid of impurity that must create its own writing and politics, and must write its own origin story and future, not as a part "pure" heteronormative culture, or as an option within normativity's binaries, 
but as something that exists as a new state, as a fusion of states. As Time War ends, Red and Blue have embraced one another as hybrids, and so no longer belong to Agency or Garden. They seek a cyborg culture all their own, a "bridge between our shifts" (198) that yields to neither. As Blue proposes in their final letter, the cognitive Cyborg has the power to defect "not to each other's sides, but to each other" (198). Posthuman cyborgs and monsters do not need to escape the doom of Homo Sacer by finding political life within the liberal humanist societies of "pure" human cultures, but instead escape the doom of the Homo Sacer by escaping that oppressive system entirely, by embracing the power of their hybrid bodies and the radical transformations of their apocalypses, in the power to form a politics, identity, and culture of their own, that does not need to abide by the restrictions of what they are leaving behind.

Queer bodies and the hybrid bodies of Red and Blue can find each other not through the language of binary or heteronormativity or war, but by forging that new cyborg culture through their writing, and through their cognitive states. When the queer Cyborg embraces cyborg writing and embraces the power and changes and fusions that such writing brings, then the queer body is free. To quote the final words of This is How You Lose the Time War, as the two cognitive cyborgs set out to become those new queer bodies for one another: "This is how we win." (198). 


\section{Work Cited:}

Agamben, Giorgio. Homo Sacer: Sovereign Power and Bare Life. Translated by Daniel HellerRoazen, Stanford University Press, 2016.

Braidotti, Rosi. "Posthuman Humanities.” European Educational Research Journal, vol. 12, no. 1, 2013, pp. 1-19., doi:10.2304/eerj.2013.12.1.1.

Capra, Fritjov. The Tao of Physics. Boston: Shambala, 1985.

Castro, Teresa. "The Mediated Plant." E-Flux, Sept. 2019, https://www.e-flux.com/journal/102/283819/the-mediated-plant/

Chiang, Ted. Stories of Your Life and others. Kamila.net.2016. Pdf

Chiang, Ted. Exhalation. Alfred A. Knopf, 2019.

Clark, Andy. Natural-Born Cyborgs: Minds, Technologies, and the Future of Human Intelligence. Oxford Univ. Press, 2010.

Dixon, Deborah P. "The Blade and the Claw: Science, Art and the Creation of the Lab-Borne Monster.” Social \& Cultural Geography, vol. 9, no. 6, 2008, pp. 671-692., doi:10.1080/14649360802292488.

Eagleton, Terry. Saint Oscar. Field Day, 1989.

Edelman, Lee. No Future: Queer Theory and the Death Drive. Duke University Press, 2007.

El-Mohtar, Amal, and Max Gladstone. This Is How You Lose the Time War. Saga Press, 2019.

Freeman, Elizabeth. "Introduction: Queer and Not Now," Time Binds: Queer Temporalities, Queer Histories, Duke University Press. 2010. Pdf.

Glazier, J. and Beck, T. (2018). Apocalypse, language, temporality: an alien encounter in Ted Chiang's "Story of Your Life." Subjectivity, 11(3), pp.267-284 (1-18 pdf)

Hayles, N. Katherine. How We Became Posthuman: Virtual Bodies in Cybernetics, Literature and Informatics. Univ. of Chicago Press, 2010. Print.

Haraway, Donna J. “The Cyborg Manifesto.” Manifestly Haraway, University of Minnesota Press, 2016, pp. 3-90. Print.

Judith Butler; Critically Queer. GLQ 1 November 1993; 1 (1): 17-32. doi: https://doi-org.myaccess.library.utoronto.ca/10.1215/10642684-1-1-17

Liu, Ken. The Hidden Girl and Other Stories. Saga Press, 2020.

Liu, Ken. The Paper Menagerie. Saga Press, 2016 
Moore, Alan, et al. Saga of the Swamp Thing Volume One. DC Comics, 2012.

Moore, Alan, et al. Saga of the Swamp Thing Volume Three. DC Comics, 2012.

Moore, Alan, et al. Saga of the Swamp Thing Volume Four. DC Comics, 2012.

Morton, Timothy. "Guest Column: Queer Ecology.” Pmla, vol. 125, no. 2, 2010, pp. 273-282.

Vonnegut, Kurt. Slaughterhouse-Five. NY: Dell Pub., 1991. Print 